\title{
Urodimento
}

REVISTA DE ESTUDOS EM ARTES CÊNICAS

E-ISSN 2358.6958

\section{Diálogos entre Dança na Escola e dança no TikTok. Propostas no ensino remoto}

Débora Souto Allemand

Larissa Bonfim

Para citar este artigo:

ALLEMAND, Débora Souto; BONFIM, Larissa. Diálogos entre Dança na Escola e dança no TikTok. Propostas no ensino remoto. Urdimento - Revista de Estudos em Artes Cênicas, Florianópolis, v. 2, n. 41, set. 2021.

do) DOI: http:/dx.doi.org/10.5965/1414573102412021e0112

Este artigo passou pelo Plagiarism Detection Software | iThenticate 


\title{
Diálogos entre Dança na Escola e dança no TikTok. Propostas no ensino remoto
}

\section{Débora Souto Allemand ${ }^{1}$}

Larissa Bonfim²

\begin{abstract}
Resumo
Baseado nas experiências de inserção do componente curricular Dança nos Colégios de Aplicação da UFPE e da UFRGS no ano de 2020, o trabalho compartilha proposições de atividades remotas de criação em dança a partir de ferramentas do TikTok. A pesquisa reflete sobre os pressupostos teórico-metodológicos dessas propostas em busca de uma práxis dialógica, tendo o recurso Duetos do aplicativo como uma possível metáfora para a construção do conhecimento em Dança na Escola. Observa-se que esta pesquisa artístico-pedagógica foi um interessante meio de compreensão das referências de dança da juventude, o que possibilitou a investigação em Dança, por docentes e estudantes, de forma horizontal, criativa e contextualizada.
\end{abstract}

Palavras-chave: Educação básica. Pedagogia da dança. Redes sociais. Pandemia de COVID-19. Dialogicidade.

\section{Dialogues between Dance at School and Dance at TikTok. Proposals in remote educacion}

\begin{abstract}
Based on the experiences of Dance as a school subject at UFPE and UFRGS Application Schools in 2020, this work shares propositions of remote dance creation activities using TikTok. The research reflect on the theoretical-methodological assumptions of these proposals in search of a dialogical praxis, using the application duets resource as a possible metaphor for the construction of knowledge in Dance at school. It is observed that this artistic-pedagogical research was an interesting way of understanding the references of dance of the youth, which allowed the investigation in Dance, by teachers and students, in a horizontal, creative and contextualized way.
\end{abstract}

Keywords: Basic education. Dance pedagogy. Social networks. COVID-19 pandemic. Dialogicity.

${ }^{1}$ Doutoranda em Artes Cênicas pela Universidade Federal do Rio do Grande do Sul (UFRGS). Mestrado em Arquitetura e Urbanismo, Licenciada em Dança e Arquiteta e Urbanista ambas pela Universidade Federal de Pelotas (UFPel). Professora de Dança do Colégio de Aplicação da UFRGS. deborallemand@hotmail.com (9) http://lattes.cnpq.br/2809172806147764

(iD https://orcid.org/0000-0001-8479-9822

${ }^{2}$ Mestranda no Programa de Pós-graduação em Dança da Universidade Federal da Bahia (UFBA). Bacharel em Dança e Licenciada em Artes - Dança pela Universidade Estadual de Campinas (Unicamp).

Professora de Dança do Colégio de Aplicação da Universidade Federal de Pernambuco (UFPE). larissa.bonfim@ufpe.br 


\section{Diálogos entre Danza en la Escuela y Danza en TikTok.}

Propuestas en el ensino remoto

\section{Resumen}

Basado en las experiencias de insertar el componente curricular de Danza en los Colegios de Aplicación de UFPE e UFRGS en 2020, el trabajo comparte propuestas de actividades de creación de danza remota utilizando herramientas TikTok. La investigación reflexiona sobre los supuestos teórico-metodológicos de estas propuestas en busca de una praxis dialógica, utilizando la aplicación del recurso Duetos como posible metáfora para la construcción del conocimiento en Danza en la Escuela. Se observa que esta investigación artístico-pedagógica fue una forma interesante de entender los referentes de la danza de los jóvenes, que permitió la investigación en Danza, por parte de profesores y alumnos, de manera horizontal, creativa y contextualizada.

Palabras clave: Educación básica, Pedagogía de la danza. Redes sociales. Pandemia COVID-19. Dialogicidad. 


\section{Dança na escola pública em tempos de ensino remoto}

A Dança no currículo das escolas de Educação Básica brasileiras, ensinada por docentes com formação em Licenciatura em Dança, é um campo jovem e em crescimento. A grande maioria das instituições ainda tem como responsável pela disciplina de Arte uma pessoa ${ }^{3}$ da área de Artes Visuais ${ }^{4}$, embora, nos últimos anos, a abertura de concursos específicos para cada uma das quatro linguagens discriminadas na Lei 13.278 (Brasil, 2016) tenha possibilitado o aumento do número de profissionais de cada área nas escolas (Corrêa e Santos, 2019).

No entanto, ainda que a Dança não esteja colocada como componente curricular, constata-se que ela já habita a escola em diversas instâncias e de diversas formas (Corrêa e Santos, 2019; Strazzacappa e Morandi, 2006). É possível destacar, com base nos textos citados e em nossa experiência como professoras da Educação Básica, que a dança está presente, de forma bastante expressa, como conteúdo do componente curricular Educação Física, bem como ela também tem espaço como atividade extraclasse. Além disso, encontra-se nos corpos e discursos de estudantes que se movem de diversas maneiras e a partir de diferentes referenciais de dança, muitos deles ensinados pela mídia (Santos, 2009; Strazzacappa, 2001).

Isso tudo contribui para a constituição do imaginário de dança da comunidade escolar e as expectativas para o ensino desta linguagem artística geram muitas perguntas por parte do corpo discente a respeito do que pode vir a ser feito nas aulas de Dança ${ }^{5}$, ou seja, quais tipos de danças serão aprendidos. Esta é uma

\footnotetext{
${ }^{3}$ Adotamos, neste artigo, o uso da linguagem não sexista (Franco e Cervera, 2006), mesmo tendo consciência da dificuldade de reaprender a escrita e a leitura da língua portuguesa, que, em geral, utiliza o genérico no masculino. Porém, nos colocamos em processo de mudança por entendermos a necessidade de incluir todas as pessoas de todos os gêneros na sociedade e na escrita.

${ }^{4}$ No caso dos Colégios de Aplicação da UFPE e UFRGS, contextos em que estamos inseridas, diferente da maioria das redes, não há o componente curricular Arte, denominado com nome genérico. Porém, Artes Visuais, Música e Teatro configuram-se há bastante tempo como componentes curriculares independentes e a inserção da Dança como disciplina aconteceu somente em 2019, com nossa nomeação como professoras efetivas das escolas.

5 Utilizamos a expressão Dança com a inicial em maiúscula quando se tratar desta linguagem como componente curricular ou disciplina no ensino formal da Educação Básica.
} 
questão recorrente, compartilhada por docentes com formação em Licenciatura em Dança nos mais diferentes contextos. A palavra Dança ganha diferentes significados a depender do sujeito que a pronuncia. Alguns dizem que gostam muito de dança, outros, que não gostam de jeito nenhum. Mas, afinal, de que dança estamos falando? Strazzacappa (2001, p.71) nos ajuda a elaborar um pouco sobre isso:

Quando se fala em dança na escola, milhares de imagens começam a povoar nossas mentes. [...] Ao chegarmos nas instituições, costumamos interrogar as crianças e os adolescentes sobre sua compreensão de dança. É interessante observar que, se há alguns anos atrás, a primeira imagem que vinha à mente destes jovens era a figura da bailarina clássica nas pontas dos pés, hoje essa imagem (embora ainda presente) já está sendo substituída por outras trazidas pela mídia. As respostas variam entre as dançarinas do "Tchan" e algumas popstars norte americanas (nota-se a predominância da figura feminina). Quando interrogados, então, sobre o que querem aprender numa aula de dança, as respostas se multiplicam, indo do ballet clássico às danças de rua.

Dado que o texto de Strazzacappa (2001) é do início do século, vinte anos depois, aquelas múltiplas respostas se somam ao interesse pelo funk, pelo brega, pelo passinho, pelo Hip Hop, pela Fitdance ${ }^{6}$, pelo $K-p o p^{7}$ e, especialmente desde o ano de 2019, as danças e o modo de produzir dança que circulam no TikTok também habitam os referenciais da juventude. Este foi o aplicativo mais baixado na App Store no ano de 2019 (CANAL TECH, 2020) e, durante a pandemia de 202021, tem alimentado os imaginários de dança de uma grande quantidade de jovens estudantes, especialmente daquelas pessoas vinculadas ao Ensino Fundamental Il e ao Ensino Médio. A plataforma, além de ser uma rede social, possibilita a edição rápida de vídeos curtos, com o uso de recursos como efeitos, filtros, sons, textos, entre outros, e tem conteúdos intimamente relacionados à Dança em hashtags como \#dancinhas, \#dancinhasdotiktok, \#dancetutorial, \#desafiodedança, \#dancechallenge.

Assim, com nosso recente ingresso como professoras efetivas dos

6 Fitdance é uma atividade aeróbica na qual coreografias, elaboradas a partir de mistura de ritmos, são reproduzidas com o intuito de gasto calórico.

${ }^{7}$ K-pop, abreviação de korean pop, é uma dança relacionada a um gênero musical sul-coreano. 
Colégios de Aplicação da UFPE e da UFRGS (CAp/UFPE e CAp/UFRGS) ${ }^{8}$, ao final do ano de 2019, além de termos de lidar com todas as expectativas para o ensino de Dança que já circulavam na comunidade escolar num período pré-pandemia de COVID-199, agora também precisamos conhecer as novas danças que estão sendo produzidas no período de distanciamento social, para saber como lidar com elas em nossas salas de aula. Isso porque compreendemos que a educação só é possível de acontecer de fato quando há diálogo entre os indivíduos envolvidos no processo de ensino-aprendizagem, ou seja, nos entendemos como professoras dispostas ao diálogo com os saberes da comunidade escolar (Freire, 2019).

Em se tratando de uma educação em dança que passa a acontecer durante o ano letivo de 2020, ano marcado pelo trabalho remoto e pelo uso de dispositivos digitais como forma de completar o processo de ensino-aprendizagem, olhamos para as redes sociais e para as danças ali presentes como forma de compreender um dos contextos das juventudes escolares. Percebemos esta semelhança entre nossos contextos no sul e no nordeste do Brasil, apesar de as formas de organização para o ensino remoto acontecerem de maneiras distintas.

Identificar que uma grande parte do número de estudantes dos Colégios de Aplicação da UFPE e da UFRGS representa a geração TikTok, interessada em Dança através do estímulo das referências contidas na plataforma, gerou a necessidade de diálogo com essa mídia. Assim, nós, professoras de Dança de diferentes instituições, mas com indagações muito próximas, desenvolvemos a presente pesquisa conjuntamente, para análise dos princípios estéticos das produções em dança do TikToke proposição criativa para as turmas de estudantes nas atividades pedagógicas remotas nas respectivas unidades acadêmicas.

É importante ressaltar que esta pesquisa de Dança na Escola relacionada ao TikTok poderia ter acontecido ainda que o trabalho remoto emergencial não fosse uma realidade. No entanto, os desafios apresentados por essa modalidade de

${ }^{8}$ Colégios de Aplicação são unidades acadêmicas de educação básica vinculadas a Instituições de Ensino Superior. São campos de experimentação e inovação pedagógica e espaço de formação para estudantes das diversas Licenciaturas.

${ }^{9}$ COVID-19 é uma doença respiratória causada pelo vírus SARS-CoV-2, pertencente à família dos coronavírus, que pode levar à óbito. No Brasil, a Organização Mundial de Saúde decretou, no dia 11 de março de 2020, estado de pandemia. 
ensino são inúmeros e, sem dúvida, a elaboração de atividades que partem das vivências e interesses dos grupos de estudantes a fim de reforçar o estímulo para a participação orientou fortemente o desenvolvimento da proposta.

Ao longo deste período de ensino remoto, pudemos perceber o quanto as atividades pedagógicas síncronas e assíncronas são desgastantes para docentes e estudantes. Especialmente para as pessoas adolescentes estudantes, o distanciamento social foi de grande impacto, a falta de convivência com colegas e com o ambiente escolar tem gerado problemas relacionados à saúde mental, e, em geral, o corpo discente tem exposto uma sensação constante de sufocamento devido a sobrecarga de tarefas, fato também constatado por Valle e Ivanoff (2021, p.13) em seus contextos de ensino: "O ERE exige um trabalho de autonomia, maturidade e organização por parte dos alunos, que muitas vezes passavam por momentos tensos devido à pandemia e sem condições emocionais de atender às disciplinas." Assim, pensamos que também cabe a nós, professoras, ter sensibilidade para proporcionar atividades educativas mais adequadas ao período pandêmico.

A pesquisa que desenvolvemos, relacionando ensino formal de Dança e redes sociais, então, intencionou uma maior aproximação com o corpo discente para a construção de relações significativas de ensino-aprendizagem, movimento tão necessário em todos os contextos, ampliado ainda mais nestes tempos remotos. Assim, este trabalho objetiva compartilhar e refletir sobre a atuação pedagógica no ensino remoto formal de Dança nos CAps UFPE e UFRGS no ano letivo de 2020, ocorrido a partir do uso de recursos e ferramentas do aplicativo TikTok.

Os dados utilizados na pesquisa foram produzidos nas atividades realizadas por estudantes de Dança dos referidos Colégios e, no caso das imagens que aparecem os corpos e rostos das alunas e dos depoimentos escritos por elas, tanto as estudantes quanto as pessoas que são suas responsáveis legais autorizaram a participação na pesquisa através da assinatura de Termos de Assentimento e de Termos de Consentimento Livre e Esclarecido ${ }^{10}$.

10 Parte do material está vinculado à pesquisa "Currículo em Movimento: inserção da Dança no Colégio de Aplicação da UFRGS”, aprovada na UFRGS sob o número 38273. O envolvimento de estudantes do Ensino Fundamental e Médio como sujeitos de pesquisa foi submetido à Plataforma Brasil e encaminhado e aprovado pelo Comitê de Ética em Pesquisa do Hospital Ernesto Dorneles, segundo os trâmites de ética em 
Assim, como parte desta busca por dialogicidade no processo educativo (Freire, 2019) e com o desejo de conhecer e aprender com as produções de dança que estão "na moda" entre as comunidades jovens durante o período de distanciamento social, criamos o perfil @dancap2020, administrado por nós, professoras de Dança das referidas escolas e autoras deste trabalho.

\section{O perfil @dancap2020 no TikTok}

A criação do perfil aconteceu no mês de maio, depois de um certo período de "namoro" com o TikTok, ainda numa etapa da pandemia onde tudo era muito novo e a nossa atenção às formas de produção e ensino de Dança nas redes sociais era bastante forte. Por um lado, nossas preferências estéticas, concepções de criação e ensino de dança nos afastavam dos modos de produção das "dancinhas"11 do TikTok, que, a primeira vista, nos pareciam deveras reprodutivistas e simplistas. Mas, por outro lado, mobilizadas pela potência do diálogo, em função da recente carreira nos CAps e também em função do distanciamento social, estávamos em busca do universo de dança trazido pelo corpo discente. Procuramos, então, realizar verdadeiros Duetos ${ }^{12}$ com este grupo de estudantes, almejando a criação em Dança a partir das subjetividades e investigando os recursos da plataforma, nos jogando de corpo inteiro nesta empreitada.

Para nossa surpresa, a plataforma mostrou-se bastante aberta para diversas possibilidades criativas, especialmente em função dos efeitos, filtros e ferramentas de edição de vídeo. Além de conhecer o aplicativo, a proposta acabou sendo também uma oportunidade para "seguirmos" e "sermos seguidas" por estudantes que cursavam o componente curricular Dança naquele momento em nossas escolas, estabelecendo vínculos sociais.

Em geral, as dancinhas aprendidas na plataforma apresentam um vocabulário próprio, são executadas em uma relação frontal com as câmeras e os movimentos

${ }^{11}$ É importante ressaltar que a palavra "dancinha", no diminutivo, não tem qualquer sentido de desvalorização, essa expressão é a forma como jovens se referem às coreografias de dança do TikTok.

${ }^{12}$ Duetos são uma modalidade de interação com outras pessoas que também possuem perfil no aplicativo. Falaremos mais adiante sobre isso. 
corporais são realizados com a parte superior do tronco, com ênfase nos braços. Por se tratar de uma codificação de gestos, vários vídeos compartilhados ensinam as coreografias através de tutoriais. Muitos deles são organizados com uma sequência de emojis ${ }^{13}$ ou de palavras na lateral ou na parte superior da tela, indicando os movimentos que devem ser feitos a partir da relação com os símbolos. Este recurso dos tutoriais desde o início chamou nossa atenção e nos pareceu oferecer possibilidades para aprofundar a experiência de ensino de Dança na escola. As proposições desenvolvidas neste sentido serão compartilhadas neste trabalho mais adiante.

Outro recurso muito presente na plataforma são os efeitos. Estes, apesar de não serem tão frequentemente utilizados em vídeos de dança especificamente, se fazem presentes principalmente em vídeos de humor, pois os tornam mais atrativos e divertidos. Muitas trends ${ }^{14}$ popularizam o uso de determinados efeitos e geram a oportunidade de criações diferentes a partir deles. Esse recurso também foi transformado em um dispositivo para processos de criação de Dança com estudantes do Ensino Fundamental e Ensino Médio e será descrito e analisado durante o relato da experiência no CAp/UFPE.

Por fim, gostaríamos de destacar o recurso dos Duetos (figura 1). Nesta proposta, dois ou mais vídeos podem ser colocados na mesma tela, lado a lado ou divididos na parte superior e inferior. Trata-se de uma forma de estabelecer relação direta com outras pessoas que possuem conta no TikTok, conhecidas ou desconhecidas, e criar novos vídeos a partir destes encontros. A possibilidade de interagir virtualmente, a partir do material compartilhado por alguém e desenvolver diálogos não apenas de cópia, mas de diversos modos por oposição ou complementaridade, despertou, como os recursos anteriores, a elaboração de procedimentos de Dança para as aulas.

\footnotetext{
${ }^{13}$ A palavra emoji vem da união de palavras em japonês que significam imagem e letra. Ou seja, são símbolos que representam uma ideia; eles têm a aparência de expressões, objetos, animais, entre outros, e são utilizados em diversas redes sociais.

${ }^{14}$ As trends são as tendências do momento do aplicativo. São os desafios, músicas, coreografias, dublagens que estão em alta, ou seja, sendo reproduzidos e recriados por diversas pessoas.
} 
Figuras 1 - Duetos horizontais e verticais com estudantes

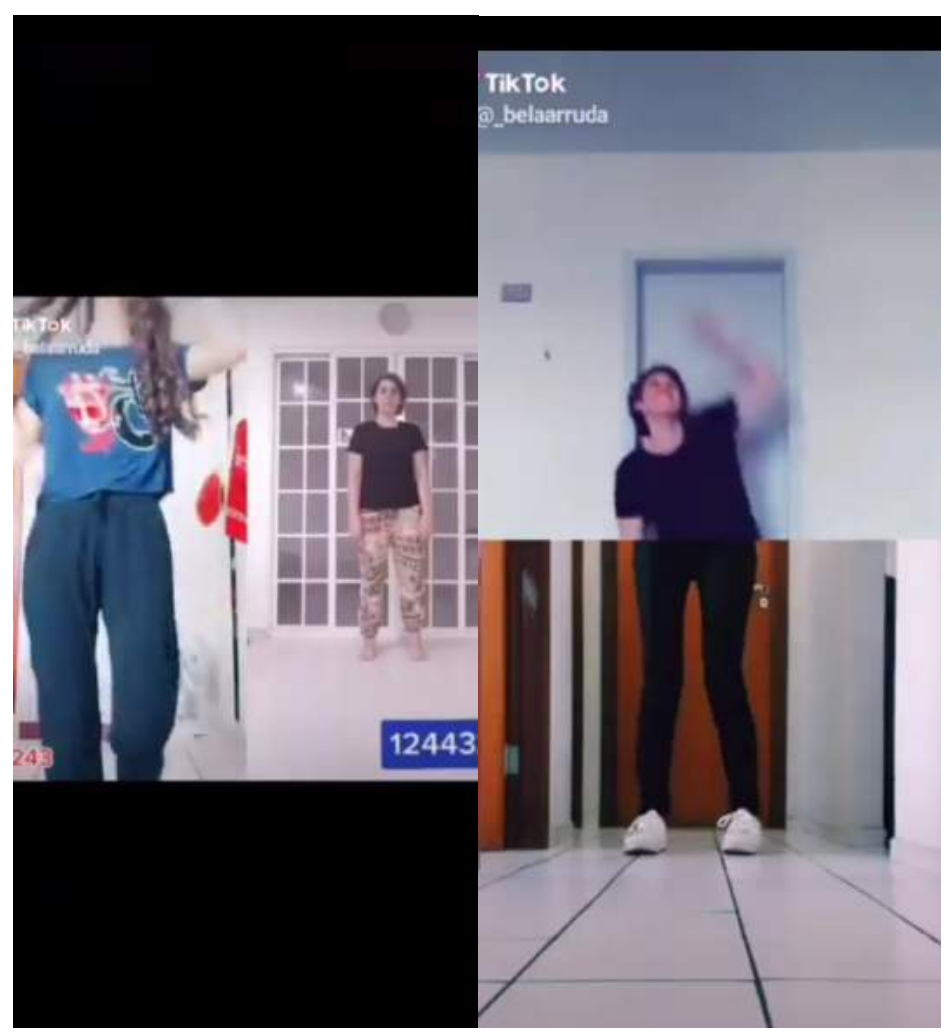

Arquivo pessoal de Larissa Bonfim

Ademais, reconhecemos nesta proposta do TikTok uma possível metáfora para nossos anseios como educadoras na busca por uma práxis dialógica na construção do conhecimento em Dança com as turmas. Como se, de alguma forma, esta experiência dos Duetos contida na plataforma traduzisse as intenções que nos moveram em direção a esta pesquisa e revelasse os pressupostos teóricos-metodológicos aos quais estamos alinhadas neste caminho para ampliação e aprofundamento do aprender e do ensinar Dança na Escola, especialmente neste momento inicial em que a Dança se encontra, como componente curricular.

\section{Duetos: Dialogicidade entre professoras e estudantes}

A educação, em uma perspectiva freiriana, é um processo contínuo e de permanente interação. Para que haja diálogo na prática educativa, é necessário 
que quem está exercendo a função da docência busque conhecer a realidade em que vivem as pessoas que estão no papel de estudantes. Porém, o estabelecimento desse diálogo dá-se de forma complexa, visto que: "Se, de um lado, não posso me adaptar ou me 'converter' ao saber ingênuo dos grupos populares, de outro, não posso, se realmente progressista, impor-lhes arrogantemente o meu saber como verdadeiro" (Freire, 2019, p.79).

Assim, para encontrar o equilíbrio entre nossos saberes de dança e os referenciais de dança de estudantes de nossas escolas, nos colocamos disponíveis a uma relação horizontal com quem estuda, na tentativa de estabelecer comunicação pois, sem ela, não há aprendizado possível. Isso significa que o trabalho com o TikTok é um exercício, uma tentativa de aprender com as danças midiáticas, fazendo uso do dispositivo de forma crítica e tendo em mente nossos objetivos para o ensino de Dança na Educação Básica, que vão em busca de proporcionar a investigação e criação de danças e de mundos através da experiência do próprio corpo em movimento, "[...] em detrimento da transferência mecânica de uma verdade codificada e externa [...]” (Peretta, 2019, p.392).

A autora Peretta, com a qual nos alinhamos, relaciona propostas contemporâneas de criação em dança com aspectos da teoria de Paulo Freire, sugerindo que a educação em dança é capaz de promover o "[...] desmascaramento dos diferentes níveis de opressão, nos quais e com os quais o indivíduo pode tomar consciência de sua condição de sujeito humano, incompleto, condicionado e transformador" (2019, p.392). Ou seja, é em busca do objetivo da conscientização de si como corpo e como sujeito que entendemos o lugar da Dança como componente curricular na escola.

Nesse sentido, a dialogicidade, para Freire, revela a opção democrática da pessoa educadora. Para o autor:

No caso da educação, o conhecimento do objeto a ser conhecido não é de posse exclusiva do professor, que concede o conhecimento aos alunos num gesto benevolente. Em vez dessa afetuosa dádiva de informação aos estudantes, o objeto a ser conhecido medeia os dois sujeitos cognitivos. Em outras palavras, o objeto a ser conhecido é colocado na mesa entre os dois sujeitos do conhecimento. Eles se encontram em torno dele e através dele para fazer uma investigação conjunta (Freire, 1986, p. 124). 
Os indivíduos, tanto estudantes como docentes, trazem uma carga de conhecimentos prévios, experiências e expectativas em relação à Dança, além das influências de sua geração e de paradigmas que orientam as suas relações com o corpo e o movimento. O diálogo, na perspectiva freiriana, é um ato de respeito às leituras de mundo da pessoa que aprende, ocorrido no momento em que o sujeito docente reconhece as potências e limitações do saber de todos os indivíduos envolvidos no processo de ensino-aprendizagem, inclusive as suas próprias. Nesse sentido, entendemos que não é possível ser professora de Dança de uma geração Tiktok sem considerar o que é produzido neste aplicativo. Identificamos uma presença bastante forte da plataforma no cotidiano adolescente e, ainda mais, sendo ela relacionada a conteúdos de Dança, assim, entendemos que "investigar a mídia, é investigar as maneiras de sermos e estarmos no mundo hoje" (Santos, 2009, p.35).

Percebe-se que o aplicativo, além de produzir novos tipos de dança e, por isso, novos discursos sobre dança, abre uma nova forma de aprender em dança. Segundo Airton Tomazzoni (Santos, 2009), as danças da mídia nos ensinam várias lições e as novas formas de se aprender dança são uma delas. Outra lição está relacionada com os novos jeitos de se acessar dança e experienciá-la. Ou seja, a mídia torna-se um dispositivo pedagógico para a dança. O autor completa:

Compreender o papel da mídia neste processo se coloca de maneira indispensável para poder constituir perspectivas educacionais para dança, que não reneguem o contexto da cultura contemporânea no qual os alunos estão mergulhados e com o qual estão constantemente interagindo. Se, num passado que remonta ao século $X V$, os manuais de dança ensinavam o quê e como dançar nas cortes européias, hoje a mídia mostra sua eficácia em também desempenhar tal função (Santos, 2009, p.25).

Assim, nos posicionamos de forma contrária à simplória crítica das limitações das danças e das perspectivas corporais presentes no aplicativo. No entanto, durante a pesquisa não nos propomos a repetir, de forma alguma, os princípios de cópia das coreografias frontais e blocadas do tronco para cima. Pelo contrário, como educadoras de Dança nos propomos à compreensão dessas danças que são referências para estudantes do Ensino Fundamental e Médio para poder ir além, provocando micro transgressões no modus operandi das danças do aplicativo e 
ampliando as possibilidades de aprendizado em Dança a partir da realidade e dos interesses do corpo discente.

Aproximando o conceito de dialogicidade de Paulo Freire com a realidade do TikTok, pensamos a educação em dança como Duetos, nos quais cada uma das partes, aprendentes e ensinantes, pode aprender com a outra, revelando a horizontalidade das relações. Nessa proposição, a interação tem condições de perpassar o lugar de transmissão (cópia), importante ao aprendizado da dança, mas levando principalmente em consideração as diversas possibilidades de diálogo da linguagem artística, constantemente criadas e recriadas nos processos de ensino-aprendizagem.

Esta busca por horizontalidade, metaforicamente traduzida pelas possibilidades de interação virtual ocorridas nas telas postas lado a lado no TikTok, também acontece nas telas divididas em partes inferior e superior. Essa composição tronco-pernas, trend do aplicativo experimentada pelo grupo de estudantes do CAp/UFPE, expõe, através da complementaridade de corpos de docentes e de estudantes, as possíveis e significativas relações entre saberes, conhecimentos, vivências e referências em dança experienciadas nos contextos educacionais. Em um horizonte de respeito à leitura de mundo de cada indivíduo e de compreensão dos seres como inconclusos, inacabados e incompletos (Freire, 2019), o aprender é posicionado como um processo de devir que organiza e reorganiza os encontros das partes. Os saberes docentes e os saberes discentes não estão em campo de disputa à medida que a pluralidade tem espaço e, ao invés de oposições, os pontos de vista se apresentam como perspectivas em transformação.

Acreditamos que, com esta pesquisa, o objeto "Dança" foi colocado sobre a mesa e o investigamos conjuntamente, docentes e estudantes, tendo em vista que o diálogo freireano não corresponde à ausência de conflito. Assim, entendemos que o confronto através do diálogo e da troca de argumentos é o que fundamenta a educação do século XXI (Delors, 2001), mas, para produzir argumentos que dialoguem com as pessoas estudantes, precisamos analisar e compreender quais são as danças que as constituem. Entendemos, também, que ser professora de Dança na escola é estar em constante processo de atualização corporal por meio 
da pesquisa artística.

\section{CAp/UFRGS: estudos dirigidos e tutoriais com emojis}

O Colégio de Aplicação da Universidade Federal do Rio Grande de Sul, desde a segunda semana de implementação das medidas de distanciamento social, em março de 2020, assumiu os Estudos Dirigidos como forma de manutenção do vínculo dos indivíduos estudantes com a escola. Tal decisão foi tomada de modo emergente pela gestão diretiva logo nos primeiros dias de paralisação das atividades presenciais, mesmo sem haver, naquele momento, indicação de qualquer instância da Universidade ou do Governo Federal sobre o que deveria ser feito.

A decisão do CAp/UFRGS, de não realizar uma simples "[...] substituição das disciplinas presenciais, em andamento, por aulas que utilizem meios e tecnologias de informação e comunicação" (Brasil, 2020, s.p.), levava em conta a falta de capacitação do corpo docente da escola para trabalhar nessa modalidade, bem como a falta ou as dificuldades de acesso de docentes e discentes às ferramentas necessárias para esse tipo de ensino. Nesse sentido, cabe ressaltar que os procedimentos adotados pela gestão da escola, de envios de atividades letivas de fácil acesso, tinham em vista abarcar a diversidade social, conjuntural e etária do grupo de estudantes que compõe a comunidade. Esta, formada por indivíduos de diversas classes sociais, provenientes de diferentes bairros de Porto Alegre, arredores e municípios próximos, com idades entre 6 e 17 anos e alguns deles com deficiências.

Na etapa de ensino onde a Dança está inserida, o Ensino Médio, os Estudos Dirigidos eram disponibilizados em formato pdf no site da escola. No decorrer do ano, definiu-se que esses estudos deveriam adotar o modelo de folha A4, utilizando no máximo três páginas, em função de uma possível necessidade de impressão, pois algumas famílias necessitavam buscar as atividades na escola, em função da falta de acesso à internet ou a equipamentos. No caso de constarem links nos arquivos dos Estudos Dirigidos, estes deveriam servir apenas como material complementar. Ou seja, as tarefas deveriam ser viáveis de serem 
completadas somente com o que constava no pdf, bem como a realização das atividades também não poderia exigir a conexão à internet ou o uso de dispositivos digitais. O retorno dos indivíduos estudantes se dava por e-mail, WhatsApp $p^{15}$ ou Instagram ${ }^{16}$ pessoais da professora, facilitando o envio de vídeos ou imagens, caso alguém assim optasse para completar a tarefa da semana.

Com a limitação do ensino através de documentos em pdf, mas também percebendo o retorno empolgado, criativo e envolvido por parte das pessoas estudantes com o uso do TikTok de forma extra oficial, a proposta de criação em dança a partir de emojis, com base nos tutoriais do aplicativo, foi uma das tarefas de Estudos Dirigidos remotos que relacionou o TikTok com o ensino formal de Dança no CAp/UFRGS. Segundo Chies e Rebs (2021, p.9), a trend \#emojidance consiste em "[...] vídeos de dança, onde o ator coloca na tela uma lista de emojis, e deve realizar uma interpretação gestual de cada emoji listado, acompanhado de uma música, criando, assim, uma coreografia”. Ou seja, foi possível recriar a referida trend nos Estudos Dirigidos em pdf em função da ênfase nas imagens (figura 2).

Figura 2 - Recorte do documento dos Estudos Dirigidos da semana 20, sobre criação em dança a partir de emojis

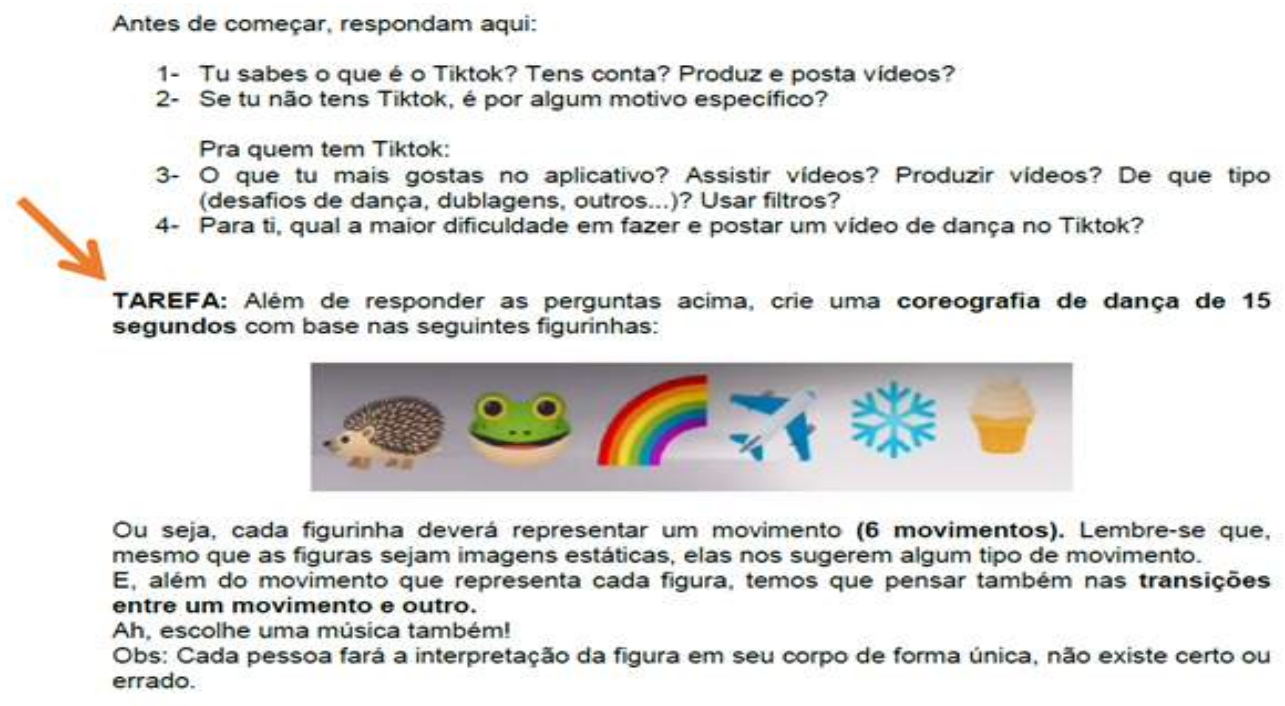

Arquivo pessoal de Débora Allemand

${ }^{15}$ WhatsAppé um aplicativo de troca de mensagens instantâneas e chamadas de voz para smartphones. Além de mensagens de texto, usuários podem enviar imagens, áudios, vídeos e documentos em pdf. Toda a comunicação é realizada por meio de conexão com a internet.

${ }^{16}$ Instagram é uma rede social de fotos e vídeos para indivíduos usuários de Androide iPhone. 
A experimentação das dancinhas com emojis, anterior à proposição da atividade para o grupo de estudantes, se deu entre as duas professoras-tiktokers, com o objetivo de compreender de que forma a proposta funcionava e de que forma poderia ser transposta ou recriada no ensino formal. No nosso caso, as figuras eram apenas uma limitação para a criação de movimentos, mas sem a necessidade de reproduzir os gestos do "repertório de dança do TikTok", pois percebemos que algumas figurinhas acabam gerando os mesmos gestos para diferentes pessoas que utilizam a plataforma. Assim, a mesma sequência de emojis produziu duas coreografias diversas nos diferentes vídeos criados por cada uma de nós (figura 3).

Figura 3 - Duas coreografias para a mesma sequência de emojis

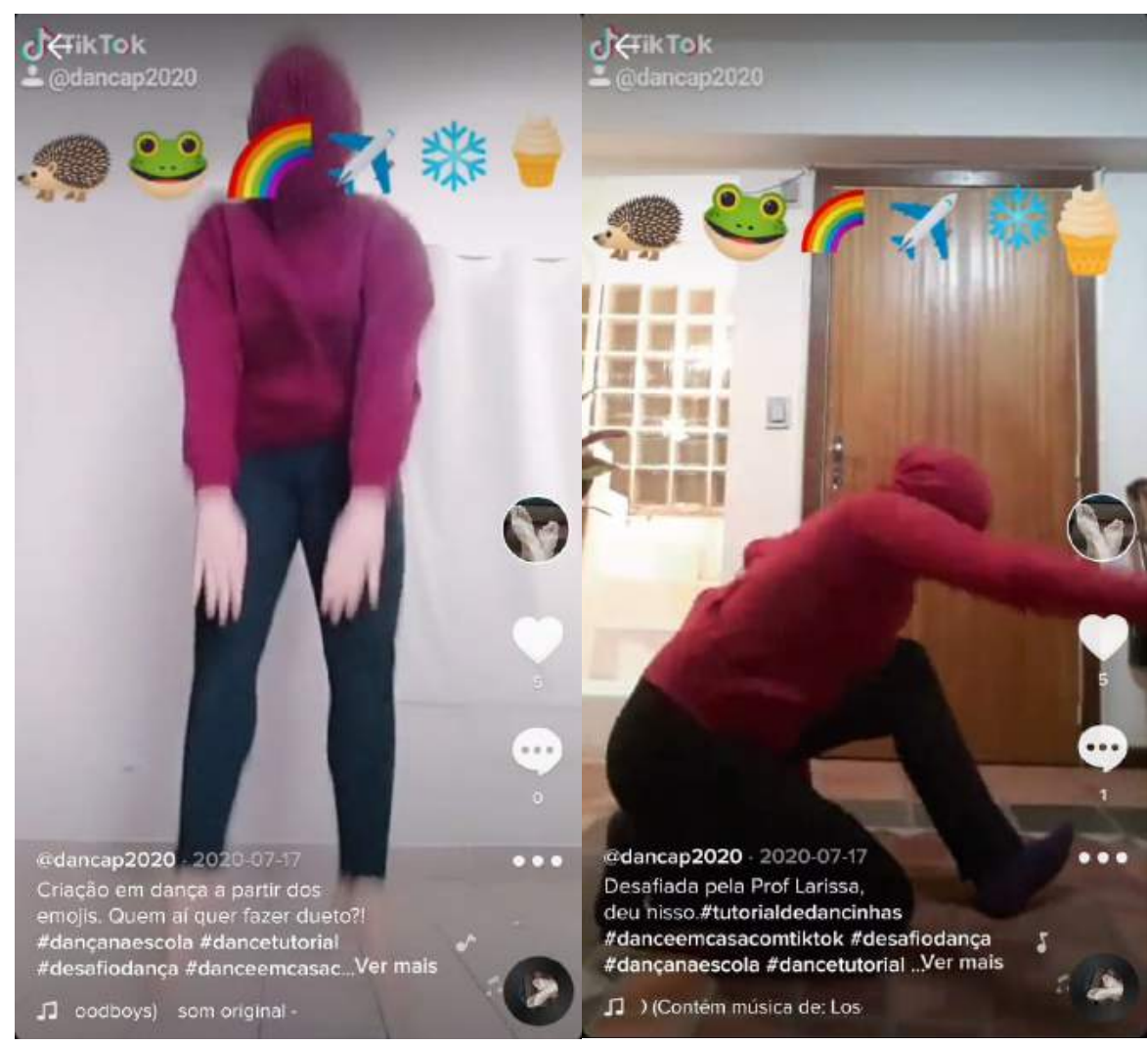

Fonte: Print de conta do aplicativo TikTok

A partir disso, uma sequência de emojis seria o disparador para a criação coreográfica da turma de estudantes em uma dada semana de Estudos Dirigidos. A ideia era que cada movimento estivesse relacionado a um emoji e a transição entre um movimento e outro deveria ser criada por cada discente individualmente, 
finalizando a coreografia com uma música. Então, foram dadas algumas sugestões para orientar a criação, por exemplo dando foco na forma física da figura ou algo relacionado ao movimento que poderia ser realizado por estes animais ou elementos da natureza que apareciam como emojis, ou ainda as figuras poderiam sugerir memórias, lembranças, sensações à pessoa que estava realizando o exercício e isso poderia produzir movimentos corporais.

Cabe ressaltar que, para completar a atividade, não havia a necessidade de possuir o aplicativo TikTok instalado no celular, pois a resposta à tarefa poderia ser tanto em vídeo (produzido ou não no TikTok), como também através da descrição dos movimentos em texto ou áudio ou, ainda, através de um relato da experiência por escrito. Porém, foi possível perceber que grande parte do grupo de estudantes produziu a tarefa por meio do referido aplicativo, utilizando, inclusive, os recursos de edição de música e de inserção de imagens no próprio vídeo dentro do TikTok (figura 4). É possível salvar os vídeos produzidos no aplicativo e enviálos para qualquer pessoa que não seja usuária do TikTok, que poderá assistir em seu celular, tablet ou computador por meio de um programa ou aplicativo para rodar vídeos.

Figura 4 - Coreografia dos emojis, pelas alunas Kethelyn, Melissa e Loren, respectivamente

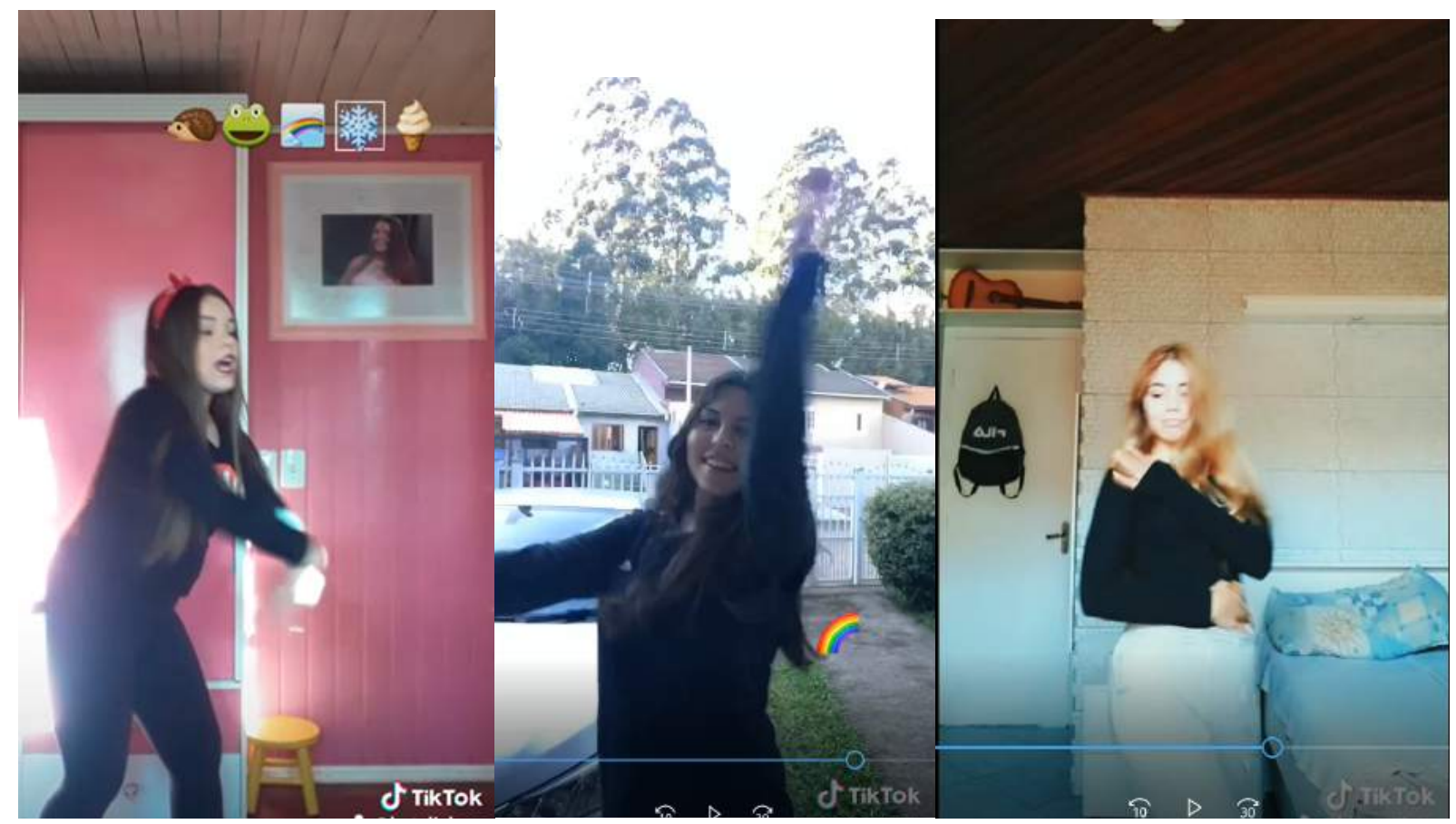

Arquivo pessoal de Débora Allemand 
Como retorno da atividade realizada, depois de algumas semanas explorando o uso dos recursos do TikTok com o grupo de estudantes de diferentes formas, foi possível perceber um engajamento na produção em dança a partir do aplicativo, como pode ser observado no relato da aluna Kethelyn, do $2^{\circ}$ ano do Ensino Médio:

Durante a pandemia eu estou fazendo muitas dancinhas do tik tok. Foi uma forma de esquecer todos os problemas que estamos passando e se conectar com meus amigos fazendo duelos de dança. Então eu estou sempre refazendo essa atividade, foi um trabalho legal e descontraído que a senhora fez conosco. Lhe agradeço muito por ter me incentivado à usar este App.

As questões a respeito da pandemia e do distanciamento social, no início do ano letivo, eram recorrentes nos Estudos Dirigidos em Dança do CAp/UFRGS, e as redes sociais, incluindo o TikTok, se mostraram fortes aliadas para enfrentar e compreender o período pelo qual estávamos passando, conforme apontado por Primo (2020, p.196):

Diante do entristecimento verificado durante o período de isolamento social, em virtude dos impactos em todos os aspectos da vida pessoal e profissional, a interação em mídias sociais mostrou-se uma importante forma de enfrentamento das dificuldades sentidas no período.

Assim, naquele momento inicial da pandemia, mais importante do que aprender determinados conteúdos de Dança, o objetivo das atividades estava mais focado no bem-estar discente e na manutenção de vínculo com a escola. Além disso, sendo a Dança no CAp/UFRGS uma disciplina recente, o objetivo da professora também era conhecer as referências de Dança da comunidade escolar, reconhecendo de que forma se dava a relação das pessoas estudantes com seus corpos. A respeito disso, quando perguntada sobre a maior dificuldade em fazer e postar um vídeo de dança no TikTok, Isabel, do $1^{\circ}$ ano do Ensino Médio, respondeu: "Achar que o vídeo ficou bom, a insegurança bate muito, mas depois quando tem o resultado se torna algo bem gratificante."

Com isso, percebeu-se que algumas pessoas têm maior facilidade para improvisar e criar suas próprias coreografias de dança quando as indicações para a criação são bastante diretas e restritas, como foi o caso da criação a partir de emojis. A maior parte do corpo discente que cursa a disciplina de Dança tem como 
referência o ensino a partir da cópia do modelo exterior, algo também bastante presente no aplicativo, porém, alguns recursos se mostraram potentes para a transformação das ideias corriqueiras de dança, como foi o caso da trend dos emojis e como também é o caso dos duetos e dos efeitos, sobre os quais trataremos a seguir, a partir das propostas de ensino-aprendizagem no CAp/UFPE.

\section{CAp/UFPE: atividades síncronas, duetos e efeitos}

No Cap/UFPE, diante da suspensão das atividades presenciais em março de 2020, a escola vivenciou um momento de paralisação no qual as pessoas servidoras ainda procuravam entender quais as medidas cabíveis. Com o intuito de conectar a comunidade escolar durante o período de distanciamento social, o site institucional "CAp na Quarentena" foi criado em junho de 2020. Nele, docentes de todos os componentes curriculares poderiam postar estudos dirigidos e também propor atividades integradoras, ou seja, encontros síncronos via Google Meet $^{77}$ de caráter transdisciplinar. Estas atividades, neste momento, eram ofertadas sem obrigatoriedade e ocorriam por adesão do corpo discente.

A preocupação com a exclusão digital foi pauta constante nas reuniões gerais do colégio neste período, assim como problematizações a respeito da transposição das atividades pedagógicas para ambientes virtuais. Diante de um trabalho cuidadoso da escola de levantamento das condições de acesso à equipamentos, internet e local de estudo, e da garantia, por parte da Reitoria da Universidade Federal de Pernambuco, de celulares/tablets e pacotes de internet para estudantes em situação de vulnerabilidade tecnológica, o corpo de servidores decidiu por iniciar o calendário letivo obrigatório de 2020 no mês de agosto.

Neste ano letivo, que se estendeu até fevereiro de 2021, o componente curricular Dança se fez presente de forma obrigatória nos $6^{\circ}$ anos, e como Parte Diversificada $^{18}$ no $9^{\circ}$ ano do Ensino Fundamental $\|$ e 1a série do Ensino Médio. A carga horária semanal do componente é de 2h/aula, divididas em 1h síncrona (via

17 Google Meet é um serviço de comunicação por videoconferência desenvolvido pela Google.

${ }^{18}$ No currículo do CAp/UFPE, os componentes da Parte Diversificada são escolhidos por cada estudante diante de algumas possibilidades. 
Google Meet) e 1h assíncrona (através da realização de atividades postadas no Google Sala de Aula $\left.{ }^{19}\right)$.

O perfil do corpo discente do Colégio da Universidade Federal de Pernambuco neste ano, estabelecido pelo modo de ingresso na escola através de seleção com provas de Português e Matemática, foi de 50\% de vagas reservadas para escola pública e 50\% livre-concorrência. Ainda que alguns aspectos desta adaptação à nova rotina escolar se apresentem como dificuldades para todo alunado, sem dúvida a falta de acessibilidade tecnológica ocorreu mais fortemente no perfil de reserva de vagas e pôde ser solucionada, de alguma forma, pela distribuição de celulares e tablets gerenciada pela Universidade.

Diante do apoio de recursos tecnológicos, foi possível desenvolver um trabalho baseado em aulas síncronas e diversas atividades assíncronas, entre elas as propostas tiktokers com o uso do aplicativo de fato. Essa experiência com a plataforma foi vivenciada no formato de um projeto intitulado "\#Dança para \#GeraçãoTikTok' e aconteceu através das proposições assíncronas juntamente com outras atividades, ainda que alguns encontros síncronos tenham sido em parte dedicados a essa discussão.

Ele foi idealizado para as realidades do $9^{\circ}$ ano e da 1 â série do Ensino Médio, que, como exposto acima, são grupos que escolhem cursar Dança como Parte Diversificada do currículo. Essas turmas, de forma geral, apresentavam interesse e intimidade com o aplicativo, o que, por um lado, gerou empolgação com a proposição do projeto, mas, por outro, certos receios.

$\mathrm{Na}$ escuta de estudantes que se mostraram resistentes à participação, foi possível perceber que nenhum dos sujeitos tinha restrições em utilizar o aplicativo, muitas vezes até já faziam uso dele em seus smartphones. Contudo, não gostariam de publicar seus vídeos. Após a compreensão de que ter o aplicativo instalado no celular seria necessário para a realização do projeto, mas que os vídeos seriam compartilhados somente como resposta à atividade e internamente

${ }^{19}$ O Google Sala de Aula, ou Google Classroom, é uma ferramenta do Google for Education que possibilita a organização e o gerenciamento dos procedimentos pedagógicos assíncronas através da criação e recebimento de atividades. Durante a pandemia, diversas instituições de ensino privadas e públicas recorreram a esta plataforma para viabilizar a continuidade das aulas de forma online. 
para fins pedagógicos se autorizado, a adesão à proposta foi total.

Durante várias semanas, proposições de criação em dança com o TikTok foram sugeridas, elas eram de caráter obrigatório e parte da carga horária assíncrona do componente curricular. Foi possível observar um retorno bastante positivo das turmas e resultados criativos a partir das propostas. A investigação artística partiu da ferramenta dos Duetos e dos efeitos do aplicativo. As orientações para as atividades foram realizadas em formato de vídeo tutorial, um cuidado que se revelou um tanto excessivo, tendo em vista que a grande maioria das pessoas estudantes já tinha familiaridade com os recursos do TikTok.

Os Duetos foram principalmente experimentados na relação entre docente e estudantes, ou seja, foram gravadas sequências coreográficas, inspiradas nas referências e músicas populares no próprio aplicativo, uma com a parte superior do corpo da professora e outra com a parte inferior (figura 1). As turmas foram convidadas a escolher um vídeo e dialogar com ele, criando a dança da parte "que faltava" e colocando seu corpo em ação naquela relação. Esta atividade gerou criações diferentes e interessantes e o relato da dificuldade, vivenciada como um desafio instigante, de sincronizar os novos movimentos elaborados com o vídeo existente.

Nesta proposta de Duetos verticais, uma estudante da $1 \underline{a}$ série do Ensino Médio, criou um vídeo com a sua parte inferior do corpo e a parte superior de um corpo de uma personagem de $A_{n i m e}{ }^{20}$ (figura 5). Esta produção despertou interesse de toda a turma e foi uma forma que a estudante encontrou de relacionar o universo da cultura Otak $u^{21}$, com o qual ela se identifica, com as proposições dos nossos encontros de Dança.

${ }^{20}$ Anime se refere aos desenhos de animação oriundos do Japão.

${ }^{21}$ Otaku é um termo japonês para pessoas com interesse especial em animes e mangás. 
Figura 5 - Dueto de dança de estudante com vídeo de anime

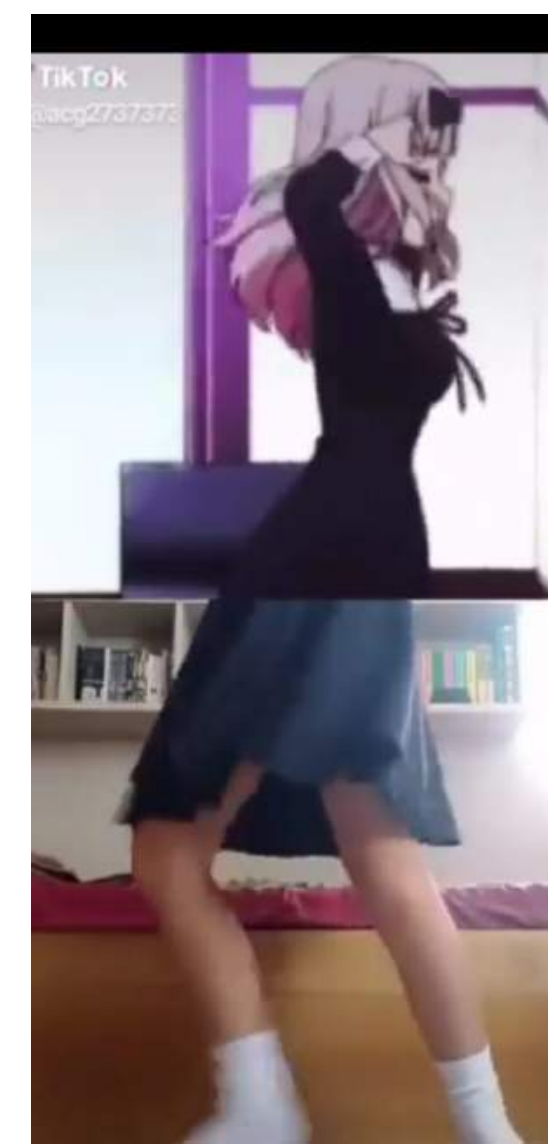

Arquivo pessoal de Larissa Bonfim

A partir do aplicativo, as criações em dança foram vivenciadas com ludicidade. O jogo, entendido como elemento fundamental para o processo criativo (Freire, 2002), esteve presente e com ele uma certa despreocupação que traz a possibilidade de descoberta de novas disposições. Criar novos arranjos imprevisíveis na relação com as referências dadas foi um fator importante nas vivências com a plataforma. Exemplos dessa criação-transformação lúdica foram os efeitos do aplicativo.

Existe uma diversidade muito grande de efeitos, que vão desde filtros que inserem acessórios ou ressaltam maquiagem no rosto até imagens que multiplicam a pessoa, distorcem o corpo, introduzem elementos, entre muitos outros. Esses efeitos, em geral, funcionam a partir do reconhecimento facial, além de muitos utilizarem os movimentos de boca e olhos como dispositivo de acionamento de algum efeito. O aplicativo também tem inteligência para fazer 
uma leitura corporal, por exemplo, ressaltando figura (corpo humano) e fundo.

Estes efeitos, utilizados mais frequentemente em trends de humor, foram investigados como possibilidade de criação em dança. Uma das primeiras experiências, que também se tornou uma das preferidas das pessoas estudantes, foi o efeito espelho (figura 6). Nele, os corpos são duplicados e é possível estabelecer uma relação com a própria imagem. Este efeito proporcionou uma espécie de versão virtual do tradicional jogo dos espelhos, muito utilizado em aulas presenciais de Dança e Teatro, realizado em duplas. Dançar em tempos de isolamento, através do encontro com sua própria imagem, pareceu fazer sentido para os grupos de estudantes, além desse recurso oportunizar sumir da tela, espelhar apenas partes do corpo, como os braços, e assim produzir efeitos visuais interessantes (figura 6).

Figura 6 - criações com o efeito espelho

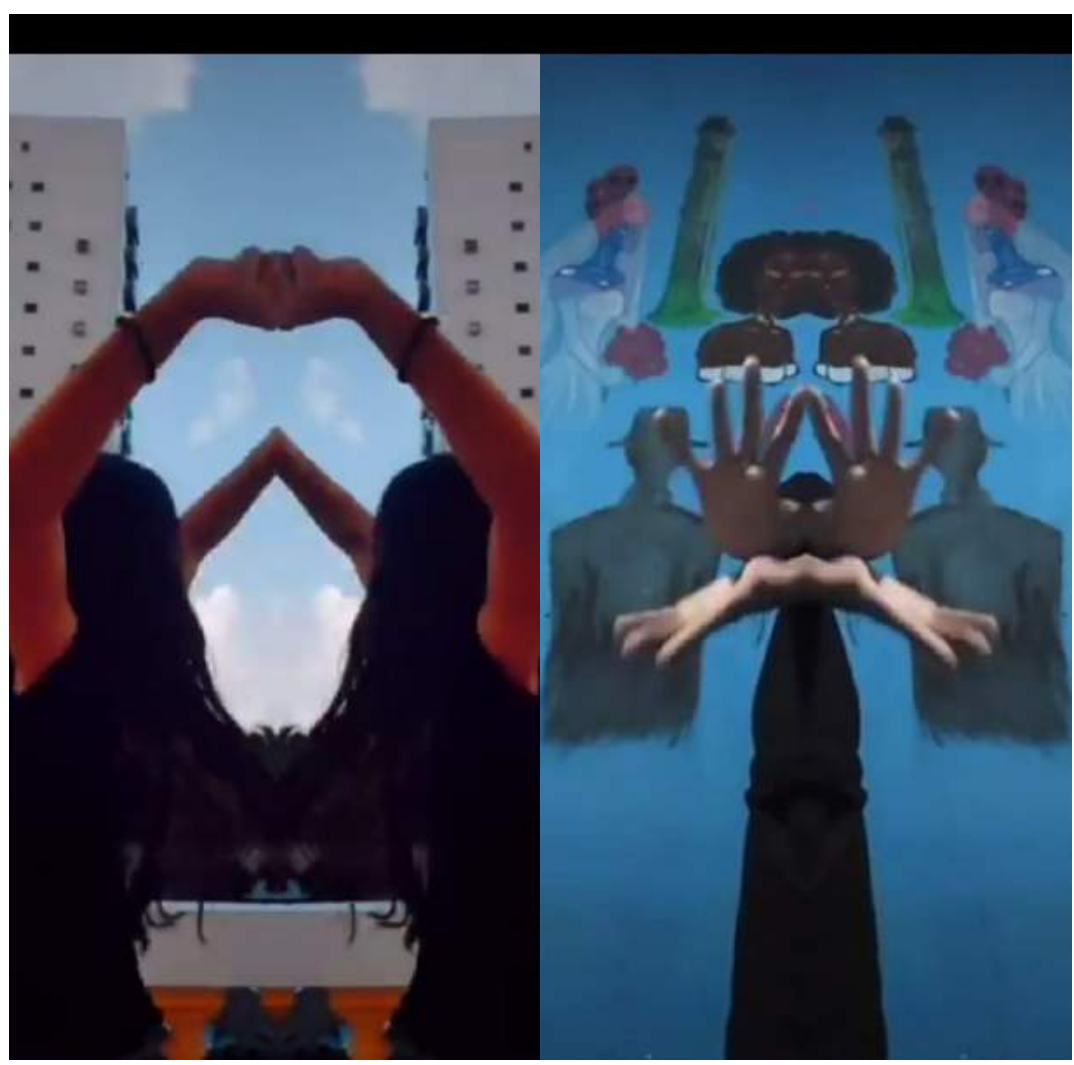

Arquivo pessoal de Larissa Bonfim

Outro efeito explorado foi a imagem congelada. Este, também muito popular em vídeos de humor, proporciona que uma imagem, em uma determinada 
posição, permaneça na tela para que a pessoa possa interagir com ela mesma. A partir do elemento labaniano ${ }^{22}$ tensões espaciais, as turmas de estudantes foram convidadas a criar formas com seu corpo no espaço para, depois de fixadas na tela, serem preenchidas pelos seus próprios movimentos (figura 7).

Figura 7 - Produção a partir do efeito imagem congelada

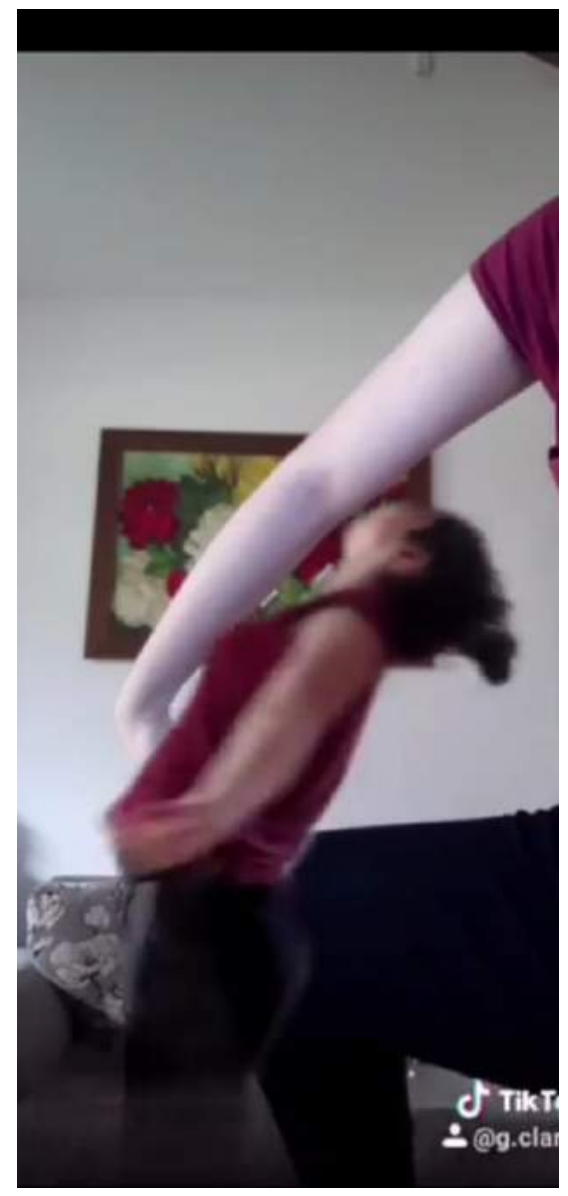

Arquivo pessoal de Larissa Bonfim

Estes foram dois exemplos de efeitos utilizados, dentre tantos outros. Com o andamento do projeto no CAp/UFPE, os grupos de estudantes que inicialmente eram orientados para criação a partir de um efeito específico do aplicativo, foram conquistando independência para desenvolver suas próprias composições. Dessa forma, todos os vídeos postados no @dancap2020 eram inspirações para suas produções, assim como todos os demais efeitos do aplicativo. Nestes processos

22 O termo labiano se refere ao trabalho de Rudolf Laban que, na primeira metade do século XX, desenvolveu um profundo estudo dos elementos constitutivos da dança. 


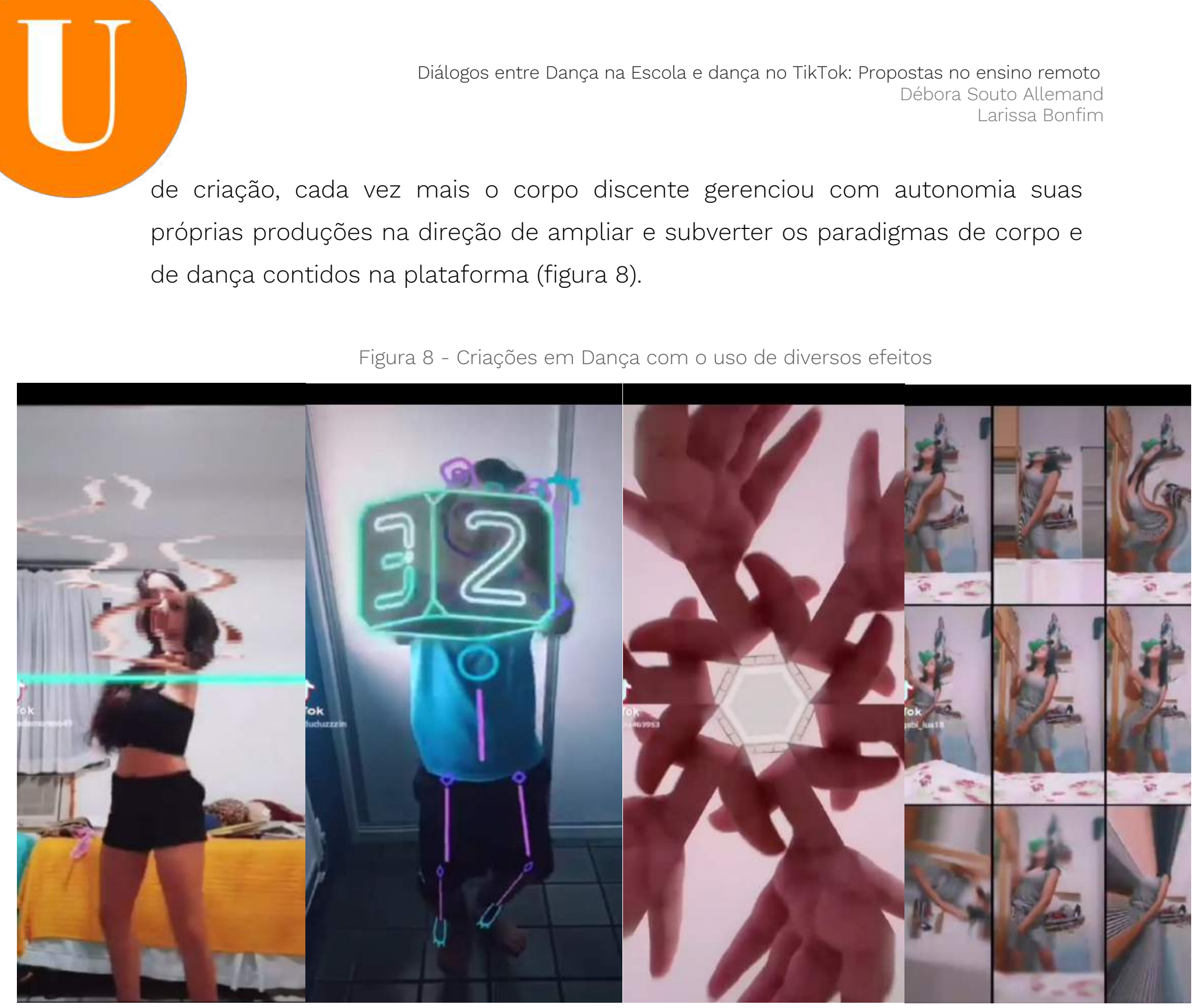

Arquivo pessoal de Larissa Bonfim

Na finalização do projeto “\#Dança para \#Geração TikTok”, cada integrante das turmas pôde selecionar algumas de suas criações preferidas. Foi organizado um compilado desses vídeos escolhidos, resultado que pode ser acessado no canal do Youtube do Colégio ${ }^{23}$. Este processo foi compartilhado no festival.comARTES ${ }^{24}$ do Colégio de Aplicação da UFPE.

${ }^{23}$ Disponível em: <https://www.youtube.com/watch?v=i-RSvJZgkhY\&t=192s>.

${ }^{24}$ O festival.comARTES foi o Festival de Artes do Colégio realizado em edição virtual em fevereiro de 2021. As produções das quatro componentes curriculares (Dança, Artes Visuais, Música e Teatro) e programações convidadas foram apresentadas através do Google Meet, Instagram e Youtube. 


\section{Considerações finais:}

Prós e contras do incentivo ao uso do TikTokentre a juventude

Apesar da organização do ensino remoto em cada uma das duas escolas ter ocorrido com determinadas especificidades, como acima detalhado, as dificuldades também parecem ser muito semelhantes, tanto por parte de docentes como de discentes: falta de acesso à conexão ilimitada de internet, ausência de equipamentos adequados, espaços domésticos transformados em salas de aula, dificuldade de auto-organização para o estudo ou mesmo falta de vontade para a realização das tarefas da escola. Além disso, também é bastante semelhante nos dois contextos questões que envolvem a inserção da Dança como componente curricular justamente no momento de ensino remoto. Com isso, nossa atenção, que já estava voltada para a compreensão do contexto escolar com relação aos conhecimentos de dança, se voltou também para as danças midiáticas e para as formas de produção em dança no aplicativo TikTok, estabelecendo um diálogo possível com as pessoas estudantes, mesmo em tempos de distanciamento social.

De modo geral, notamos que a expectativa para o ensino de Dança é aquele que acontece a partir da reprodução do modelo exterior e o TikTok, a primeira vista, parece reforçar isso. Assim, no início do projeto nos parecia um tanto incoerente reforçar o uso dessa rede social, ao mesmo tempo em que estávamos curiosas para compreender quais eram as danças que habitavam aquela rede e resolvemos embarcar no projeto para poder, de fato, fazer as críticas ao aplicativo de forma mais contundente. Tentando não se apaixonar completamente pela plataforma e nem refutá-la sem conhecer, fomos aos poucos entendendo que esta seria uma forma de manter um vínculo social com estudantes e outras pessoas, bem como uma maneira de "chegar à escola" sem impor nossos conhecimentos de dança como "corretos" ou "melhores".

O uso das tecnologias digitais trouxe discussões a respeito de corpo, movimento, espaço e imagem muito além do que poderíamos imaginar. Em momentos de avaliação desta pesquisa desenvolvida com as turmas de estudantes, a despeito do retorno bastante positivo dos grupos, pudemos 
problematizar algumas questões, dentre elas a relação com o uso das câmeras para filmagens dos exercícios ou para participação nas aulas síncronas. Para nós, professoras de Dança, esse é um debate bastante relevante, já que enfrentamos o desafio de ministrar aulas de prática de corpo e movimento muitas vezes sem ver as pessoas e até nos perguntamos se a proposta está realmente sendo realizada. Para isso, precisamos criar diferentes estratégias para a avaliação processual do ensino e o incentivo a um aplicativo que já vinha sendo bastante utilizado no cotidiano de jovens estudantes foi uma aposta para a criação de uma nova forma de ensino em Dança, através das tecnologias digitais.

Ao mesmo tempo em que observávamos que algumas das propostas tinham bastante adesão por parte das turmas, foi possível perceber o paradoxo do momento em que vivemos: grande parte das pessoas estudantes representa a geração TikTok, que é também a geração das Selfies, ansiosa pelo retorno das curtidas de postagens de sua própria imagem nas redes sociais, no entanto, nem sempre estão disponíveis para abrir a câmera ou filmar a si mesmas em exercícios de aula. A experiência de nos colocarmos no lugar de tiktokers nos deu certa compreensão a respeito das dificuldades de produzir conteúdo e postá-lo no perfil de modo público.

As dancinhas, muitas vezes experimentadas e filmadas pelas pessoas que utilizam o TikTok, nem sempre são postadas, ou seja, podem ficar salvas no perfil mas no modo privado. Com isso, percebemos que os indivíduos estudantes, ainda que em alguns momentos quisessem mostrar que sabem dançar certa coreografia, em outros, por timidez ou dificuldades com a própria autoestima, nunca chegam a tornar públicos seus próprios vídeos. E isso não acontece somente com estas pessoas jovens, mas também conosco.

Este aparente paradoxo apresenta a problemática com as câmeras e com a exposição de vídeos na internet enfrentada por docentes e discentes. A câmera nestes tempos remotos tornou-se para nós, professoras de Dança, uma espécie de substituta das tradicionais salas de dança com imensos espelhos. A nossa educação em dança foi aquela que, inicialmente extremamente vinculada ao espelho, procurou se distanciar e até negar essa prática, em um movimento de recusa também dos modos de ensino e produção em dança calcados no modelo 
exterior e na cópia. Reconhecemos a câmera frontal do celular como um espelho que grava e exibe essa imagem para o público, o que contribui para aprofundar diversos problemas relacionados à autoimagem e a autoestima já tão presentes no processo de adolescência e que se agravam no período pandêmico.

Apesar disso, foi possível observar o aplicativo como uma ferramenta muito potente de criação artística, em função de seus inúmeros recursos e da facilidade em sua utilização. A experiência nos mostrou que é possível incentivar a criação em dança, em detrimento do ensino reprodutivista, porém, também percebemos que é preciso partir das referências de Dança da comunidade escolar, para chegar a um lugar comum de ensino-aprendizagem, onde as duas partes ensinem e aprendam diferentes formas de se mover e de estar no mundo.

Ainda, com relação às questões do distanciamento social e da pandemia, o projeto parece ter sido uma válvula de escape, ora nos mostrando que é possível sobreviver ao caos, proporcionar encontros e ensinar-aprender em dança, ora sendo um espaço de tentativa de fuga do "mundo real". Enfim, o TikTok, bem como o ensino remoto, deixa evidente a necessidade de sairmos da zona de conforto como professoras e nos mostra que somos seres em processo, aprendendo sobre o mundo e recriando-o a cada instante, no encontro, no diálogo com estudantes.

\section{Referências}

BRASIL. Lei n. 13.278, de 2 de maio de 2016. Altera o § 60 do art. 26 da Lei n 9.394, de 20 de dezembro de 1996, que fixa as diretrizes e bases da educação nacional, referente ao ensino da arte. Diário Oficial da União, Brasília, 03 maio 2016.

BRASIL. Ministério da Educação. Portaria no 343, de 17 de março de 2020. Dispõe sobre a substituição das aulas presenciais por aulas em meios digitais enquanto durar a situação de pandemia do Novo Coronavírus - COVID-19. Diário Oficial da União, Brasília, 17 de março de 2020.

CANAL TECH. Tudo sobre TikTok. Disponível em: <https://canaltech.com.br/empresa/tiktok/>. Acesso em: 12 jun. 2021.

CHIES, Luiza; REBS, Rebeca Recuero. Pandemia e as motivações sociais para a produção de ciberdanças no TikTok. Revista da FUNDARTE, Montenegro, ano 21, no 44, p. 01-19, janeiro/março de 2021. Disponível em: http://.seer.fundarte.rs.gov.br/index.php/revistadafundarte/index>. Acesso em: 10 
mai 2021.

CORRÊA, Josiane Franken; SANTOS, Vera Lúcia Bertoni. Dança na escola no Rio Grande do Sul: percursos históricos e pesquisas acadêmicas. Revista DAPesquisa, Florianópolis, v. 14, n. 23, 2019. Disponível em: <http://www.revistas.udesc.br/index.php/dapesquisa/article/view/18083129142320 19034/10288>. Acesso em: 20 nov. 2019.

DELORS, Jacques. Educação um tesouro a descobrir. São Paulo: Cortez; Brasília, DF: MEC: UNESCO. (Relatório para a UNESCO da Comissão Internacional Sobre Educação para o Século XXI), 2001.

FRANCO, Paki Venegas; CERVERA, Julia Pérez. Manual para o uso não sexista da linguagem. Brasília: PROTECA/UNIFEM, 2006. Disponível em: <https://bibliotecaonlinedahisfj.files.wordpress.com/2015/03/manual-para-usonc3a3o-sexista-da-linguagem.pdf>. Acesso em: 20 abr. 2021.

FREIRE, João Batista. O jogo: entre o riso e o choro. Campinas: Autores Associados, 2002.

FREIRE, Paulo. Medo e ousadia: o cotidiano do professor. Rio de Janeiro: Paz e Terra, 1986.

FREIRE, Paulo. Pedagogia da Autonomia: saberes necessários à prática educativa. Rio de Janeiro/São Paulo: Paz e Terra, 2019.

PERETTA, Eden Silva. Presença e inacabamento: aproximações entre a dança e o pensamento crítico de Paulo Freire. Urdimento - Revista de Estudos em Artes Cênicas, Florianópolis, v. 3, n. 36, 2019. Disponível em: <https://www.revistas.udesc.br/index.php/urdimento/article/view/15807/10931>. Acesso em: 04 jun. 2021.

PRIMO, Alex. Afetividade e relacionamentos em tempos de isolamento social: intensificação do uso de mídias sociais para interação durante a pandemia de COVID-19. Revista Comunicação \& Inovação, v. 21, n. 47, 2020. Disponível em: <https://seer.uscs.edu.br/index.php/revista_comunicacao_inovacao/article/view/7 283>. Acesso em: 04 jun. 2021.

SANTOS, Airton Ricardo Tomazzoni dos. Lições de dança no baile da pósmodernidade: corpos (des)governados na mídia. Tese (Doutorado em Educação). Universidade Federal do Rio Grande do Sul, 2009.

STRAZZACAPPA, Márcia. A educação e a fábrica de corpos: a dança na escola. Cad. CEDES, Campinas, v. 21, n. 53, p. 69-83, 2001.

$<$ http://www.scielo.br/scielo.php?script=sci_arttext\&pid=S010132622001000100005\&lng=en\&nrm=iso>. Acesso em: 15 jul. 2020.

STRAZZACAPPA, Márcia; MORANDI, Carla. Entre a Arte e a Docência: a formação do artista da dança. Campinas: Papirus, 2006. 
VALLE, Flavia Pilla do; IVANOFF, Vanessa de. Dança, educação e tecnologia: a docência em tempos de pandemia. Revista da FUNDARTE. Montenegro, ano 21, no 44, p. 01-15, janeiro/março de 2021. Disponível em: http://.seer.fundarte.rs.gov.br/index.php/revistadafundarte/index>. Acesso em: 03 mai. 2021.

Recebido em: 15/06/2021

Aprovado em: 18/08/2021 